\title{
Plunging yen hits grants
}

\section{Tokyo \& London}

THE first international teams of scientists to win grants under Japan's Human Frontiers Science Programme, whose names will be announced this week, may be disappointed to find that they have not been awarded as much money as expected, because of the recent dramatic fall in the exchange rate of the yen.

Frontiers was established as a foundation in Strasbourg last year with a budget of $¥ 2,400$ million for fiscal year 1989 to support international research on the brain and molecular biology. In 1988, when the Science and Technology Agency (STA) and the Ministry of International Trade and Industry (MITI) applied for the budget, this was worth nearly $\$ 20$ million at the then exchange rate of $¥ 123$ to the dollar. But since then, the yen has gradually fallen in value, nose-diving in the past few weeks to $¥ 159$ to the dollar. This has sliced $\$ 4.3$ million ( 22 per cent) off the original value of the budget.

When grant applications were invited last year, applicants were told they could request up to $\$ 500,000$ a year for three years (a figure recommended by the Frontiers feasibility study committee in 1988). But last week, Toichi Sakata, director of STA's Frontier office, revealed to Nature that the maximum grants have had to be limited to $\$ 400,000$ a year, partly because of the fall in the value of the yen. The size of the grants also had to be reduced because more grants have been awarded than at first intended.

The original plan was to award about 20 grants in the first year, but the programme was flooded with over 200 applications (see Nature 343, 684; 22 February 1990). And at meeting in Strasbourg on 16 and 17 March, the chairmen of the two grant review committees (for the brain and molecular biology) put forward 60 applications which were rated as being of top quality and well worthy of award.

A heated debate then ensued about how many grants to award and the council of scientists finally chose 29 grants and allotted them budgets of between about $\$ 200,000$ and $\$ 400,000$ per year. Several will receive only about 50 per cent of what they originally requested. And, according to one, some projects may now be "nonviable". But others are grateful for any new source of funds.

The 29 grants go to teams made up of a total of 159 scientists. The biggest contingent (45) is from Japan, followed by the United States (36), France (23) and the United Kingdom (20). Eighty long-term postdoctoral fellowships have also been awarded, with the largest number (18) going to Japanese scientists, followed by the British (17).

One Japanese scientist close to the pro- gramme criticizes for its lack of transparency the screening process used to select successful applicants. Unsuccesful candidates may believe they were overlooked for reasons other than scientific criteria, if these are not made clear. Last year a small 'pilot' Frontiers grant programme run by MITI's New Energy and Industrial Technology Development Organization was criticized by some unsuccessful applicants because they were given no explanation for rejection, no rating of the quality of their application and no access to referees' comments. This year's full-scale programme may receive similar complaints. Raymond Bahor, from the programme's Strasbourg office, says that the 210 teams that made unsuc- cessful grant applications will not be given a rating of their applications or reasons for rejection. He says the office does not have sufficient staff to do the job.

Sakata says that there are bound to be teething problems in the first year of full-scale operation of the programme. Complaints and criticisms are inevitable, and in fact welcome. He admits that programme organizers were caught off guard by the plummeting value of the yen, because they were so busy screening applications. Although some funds have been transferred to a bank account in Strasbourg and converted to French currency, most of the fiscal 1989 budget is still in a bank in Japan in yen. In future, he says, they will consult financial experts on how best to play the international money market.

Davld Swinbanks \& Peter Aldhous

\section{Judge halts construction}

\section{Washington}

WHAT has become one of the most contentious scientific projects in recent memory took a surprise turn for the worse last week as a federal judge halted construction of the proposed Mount Graham astronomical observatory.

Environmental activists have protested that the $\$ 200$-million telescope complex would threaten about 150 endangered red squirrels that are unique to the proposed site atop the 10,700-foot Mount Graham near Tucson, Arizona.

US district judge Alfredo Marquez said he called a four-month stay on construction of the project to allow Congress to reconsider its 1988 decision to exempt the project from the US Endangered Species Act. Championed by the Arizona delegation, the congressional bill gave the University of Arizona a 'special-use authorization' to go ahead with the observatory before all environmental-impact studies were completed.

But since the passing of the legislation, several events have raised new questions about the observatory. Several environmental groups have sued the government. In a court deposition for the case, two Fish and Wildlife Service biologists testified earlier this year that pressure was put on them by their superiors to conclude that the observatory would not threaten the squirrels. Critics have charged that the University of Arizona had 'railroaded' the congressional legislation with a massive lobbying effort. And more than a third of the members of the university's ecology department recently signed a letter criticizing the institution for "scorning the few laws that do exist to protect our environment".

Although the Arizona Fish and Wildlife Service is considering preparing another 'biological opinion' on the impact of the observatory, it is making no commitments. In May, when the snow has left the mountain, the service will begin a census of the remaining squirrel population. "We don't know yet if the biological situation has changed", says Tom Smylie, assistant regional director for the agency.

University officials point out that 5.5 of the 8.6 acres of land the observatory would occupy has already been used to build a road leading to the site. "There has been no biological impact that we can detect at this point", says Michael Cusanovich, vice president for research. The university has appealed against last week's court decision, and requested an expedited ruling.

A spokesman for Representative Jim Kolbe (Republican, Arizona) says the congressman would consider removing the university's exemption from the Endangered Species Act if another biological opinion came to a different conclusion from the first. And in a radio interview last week, Senator John McCain (Republican, Arizona) suggested that it might be time to have oversight hearings to reexamine the 1988 bill. Opponents of the project say that there are at least four alternative sites in the world where the telescope would have no adverse environmental impact.

If the university appeal is denied, the court-ordered stay could mean a substantial delay for the observatory, says project leader Peter Strittmatter. Because the construction season on the mountain is shortened by snow, a four-month postponement could set the project back an entire season, he says. A congressional reversal of the 1988 Endangered Species exemption could set it back even further.

G. Christopher Anderson 